\title{
Development of Molecular Markers for Detection of Acidovorax citrulli Strains Causing Bacterial Fruit Blotch Disease in Melon
}

\author{
Md. Rafiqul Islam, Mohammad Rashed Hossain, Hoy-Taek Kim *, \\ Denison Michael Immanuel Jesse ${ }^{\circledR}$, Md. Abuyusuf, Hee-Jeong Jung, Jong-In Park and \\ Ill-Sup Nou *
}

Department of Horticulture, Sunchon National University, Suncheon, Jeonnam 57922, Korea; rafiq@pstu.ac.bd (M.R.I.); m.r.hossain@bau.edu.bd (M.R.H.); michaelijesse@gmail.com (D.M.I.J.); yusuf_agr@pstu.ac.bd (M.A.); gml79wjd@sunchon.ac.kr (H.-J.J.); jipark@sunchon.ac.kr (J.-I.P.)

* Correspondence: htkim@sunchon.ac.kr (H.-T.K.); nis@sunchon.ac.kr (I.-S.N.); Tel.: +82-61-750-3249 (I.-S.N.)

Received: 4 May 2019; Accepted: 31 May 2019; Published: 2 June 2019

check for updates

\begin{abstract}
Acidovorax citrulli (A. citrulli) strains cause bacterial fruit blotch (BFB) in cucurbit crops and affect melon significantly. Numerous strains of the bacterium have been isolated from melon hosts globally. Strains that are aggressively virulent towards melon and diagnostic markers for detecting such strains are yet to be identified. Using a cross-inoculation assay, we demonstrated that two Korean strains of $A$. citrulli, NIHHS15-280 and KACC18782, are highly virulent towards melon but avirulent/mildly virulent to the other cucurbit crops. The whole genomes of three A. citrulli strains isolated from melon and three from watermelon were aligned, allowing the design of three primer sets (AcM13, AcM380, and AcM797) that are specific to melon host strains, from three pathogenesis-related genes. These primers successfully detected the target strain NIHHS15-280 in polymerase chain reaction (PCR) assays from a very low concentration of bacterial gDNA. They were also effective in detecting the target strains from artificially infected leaf, fruit, and seed washing suspensions, without requiring the extraction of bacterial DNA. This is the first report of PCR-based markers that offer reliable, sensitive, and rapid detection of strains of $A$. citrulli causing BFB in melon. These markers may also be useful in early disease detection in the field samples, in seed health tests, and for international quarantine purposes.
\end{abstract}

Keywords: Acidovorax citrulli; bacterial fruit blotch; melon; molecular marker; polymerase chain reaction; whole-genome alignment

\section{Introduction}

Acidovorax citrulli, formerly Acidovorax avenae subspecies citrulli (A. citrulli), is an aerobic, mesophilic, gram-negative, and seed-borne bacterium belonging to the beta subdivision of the Proteobacteria [1]. This bacterial pathogen causes bacterial fruit blotch (BFB) disease [1,2] and represents a serious threat to cucurbit crops, mainly melon (Cucumis melo L., Cucurbitaceae) and watermelon (Citrullus lanatus L., Cucurbitaceae), worldwide, including South Korea [3-6]. The disease was first reported in Georgia, United States (US) in the mid-1960s. However, it gained importance in the late 1980s and early 1990s [7] when severe outbreaks of the disease caused complete yield losses in commercial watermelon fruit production fields in several states of the US [8-10]. In fact, extensive infections in the mid-1990s incited a period of "high stakes" lawsuits against seed companies by growers, causing a near shutdown of watermelon production in the US in 1995 [11].

Since then, BFB disease has been reported in 22 countries [4] and is considered the most serious threat to watermelon, melon, and other cucurbit crops such as citron melon, prickly paddy melon, 
pumpkin, cucumber, squash, and several types of gourds in many regions of the world [3,12-17]. In melon, $\mathrm{BFB}$ is estimated to cause $80 \%$ to $100 \%$ loss in production under favorable environmental conditions, especially during rainy seasons and highly fluctuating temperature regimes [18-20]. In South Korea, BFB in melon was first reported in 1990, and several outbreaks have been observed in recent years [21].

The global spread of the disease can be attributed to the inadvertent distribution of contaminated commercial seeds, infected transplants, or alternative hosts and to the changes in population structure of the causal agent $[4,15,22,23]$. To prevent distribution of the disease, many countries, including the United States, China, and Europe, have already imposed import restrictions on contaminated seeds and plant materials [24]. In addition, use of pathogen-free seeds and transplants is recommended, as chemical control of infected plants is only partly or moderately successful [23]. Early detection of the pathogen from asymptomatic fields is likely to be helpful in employing timely control measures against the disease. Thus, the development of efficient, reliable, and sensitive diagnostic tools for detecting A. citrulli strains is necessary [24]. A. citrulli strains were previously detected by differential or semi-selective agar media [25,26], seedling grow-out, sweat box or dome assays [27], carbon source utilization profiles, fatty acid methyl esters and serological assays [28-35], and matrix-assisted laser desorption/ionization time-of-flight mass spectrometry (MALDI-TOF MS) and Fourier transform infrared (FTIR) spectra [36]. A self-paired colloidal gold immune chromatographic test strip (Sa-GICS) [37], Raman hyperspectral imaging [38], surface plasmon resonance (SPR) imaging [34], lateral flow immune chromatographic strip (ICS) [39], cross-priming amplification (CPA)-based isothermal DNA amplification [40], and visual loop-mediated isothermal amplification (LAMP) [41] also used for A. citrulli strains detection. Although these techniques have unique advantages, they can be expensive, laborious, and lengthy; may require extensive prior knowledge of the morphological and biochemical properties of the strains. Sometimes skilled manpower, and specialized equipment's are needed during detection of closely related strains [42].

Polymerase chain reaction (PCR)-based assays, on the other hand, are advantageous as they offer reliable, quick, and sensitive detection of pathogenic bacterial agents. Several PCR-based assays have been successfully used for detection of $A$. citrulli strains, such as classical PCR; dye-based quantitative PCR, ethidium monoazide (EMA)-PCR [43], propidium monoazide (PMA)-PCR [24]), SYBR green-based real-time PCR [42,44], andenterobacterial repetitive intergenic consensus polymerase chain reaction (ERIC-PCR) [44,45].Contrastingly, PCR assays combined with immunological techniques [46,47], immune magnetic separation (IMS) [48], and magnetic capture hybridization [49] additionally used for the detection of $A$. citrulli strains. These PCR assays were developed to target specific genes, such as $16 \mathrm{~S}$ rDNA, internal transcribed spacer (ITS) regions, YD-repeat proteins, and hrp genes, which often lack substantial polymorphism between closely related bacterial species and thus may not be suitable for the detection of host-crop-wise virulent $A$. citrulli strains [50-52]. Recently, whole genome sequence of $A$. citrulli strains were reported in melon [50,53] and watermelon [54-56]. Most of the assays were developed to detect $A$. citrulli strains at the species level $[42,45,57-60]$ or to distinguish model group II strain AAC00-1 (more virulent to watermelon hosts) from model group I strain M6 (more virulent to all non-watermelon cucurbit hosts) [50,61].

Globally, melon production is suffering because of BFB disease. So far, no molecular marker is available for detecting $A$. citrulli strains that cause BFB in melon. In this study, we aimed to develop PCR-based novel molecular markers for detecting A. citrulli strains causing BFB in melon. For designing such primers, we used a whole-genome alignment-based approach to identify genomic fragments that are only present in A. citrulli strains that are particularly virulent towards melon. 


\section{Results}

\subsection{Pathogenicity of Acidovorax citrulli Strains NIHHS15-280 and KACC18782}

The comparative pathogenicity of two Korean A. citrulli strains, NIHHS15-280 and KACC18782 (isolated from melon; Table 1), was tested on different cucurbit crops such as melon, watermelon, cucumber, and pumpkin using a cross-inoculation assay (Figure 1).

Table 1. Plant pathogenic bacterial strains of Acidovorax citrulli and other bacterial genera used in this study.

\begin{tabular}{|c|c|c|c|}
\hline Bacterial Strains & Scientific Name & Host Plant & SC \\
\hline NIHHS15-280, KACC18782 & Acidovorax citrulli & Melon & \\
\hline $\begin{array}{l}\text { NIHHS16-088, KACC17000, KACC17001, } \\
\text { KACC18785, KACC17005, KACC17909, } \\
\text { KACC17910, KACC17911, KACC17912, } \\
\text { KACC18649, KACC18783 }\end{array}$ & Acidovorax citrulli & Watermelon & South Korea \\
\hline KACC17913 & Acidovorax citrulli & Pumpkin seed & \\
\hline KACC17002, KACC18784 & Acidovorax citrulli & Cucumber & \\
\hline KACC16207 & $\begin{array}{l}\text { Acidovorax avenae } \\
\text { subsp. avenae }\end{array}$ & Proso- millet & \\
\hline ICMP13051 & $\begin{array}{l}\text { Pseudomonas } \\
\text { syringae pv. } \\
\text { maculicola }\end{array}$ & Cabbage & New Zealand \\
\hline NIHHS1326 & Didymella bryoniae & Cucumis melo & South Korea \\
\hline
\end{tabular}

ICMP: International Collection of Microorganisms from Plants (ICMP), Landcare Centre, Auckland, New Zealand; KACC: Korean Agricultural Culture Collection, Korea; NIHHS: National Institute of Horticultural and Herbal Science, Korea; SC: Source Country.

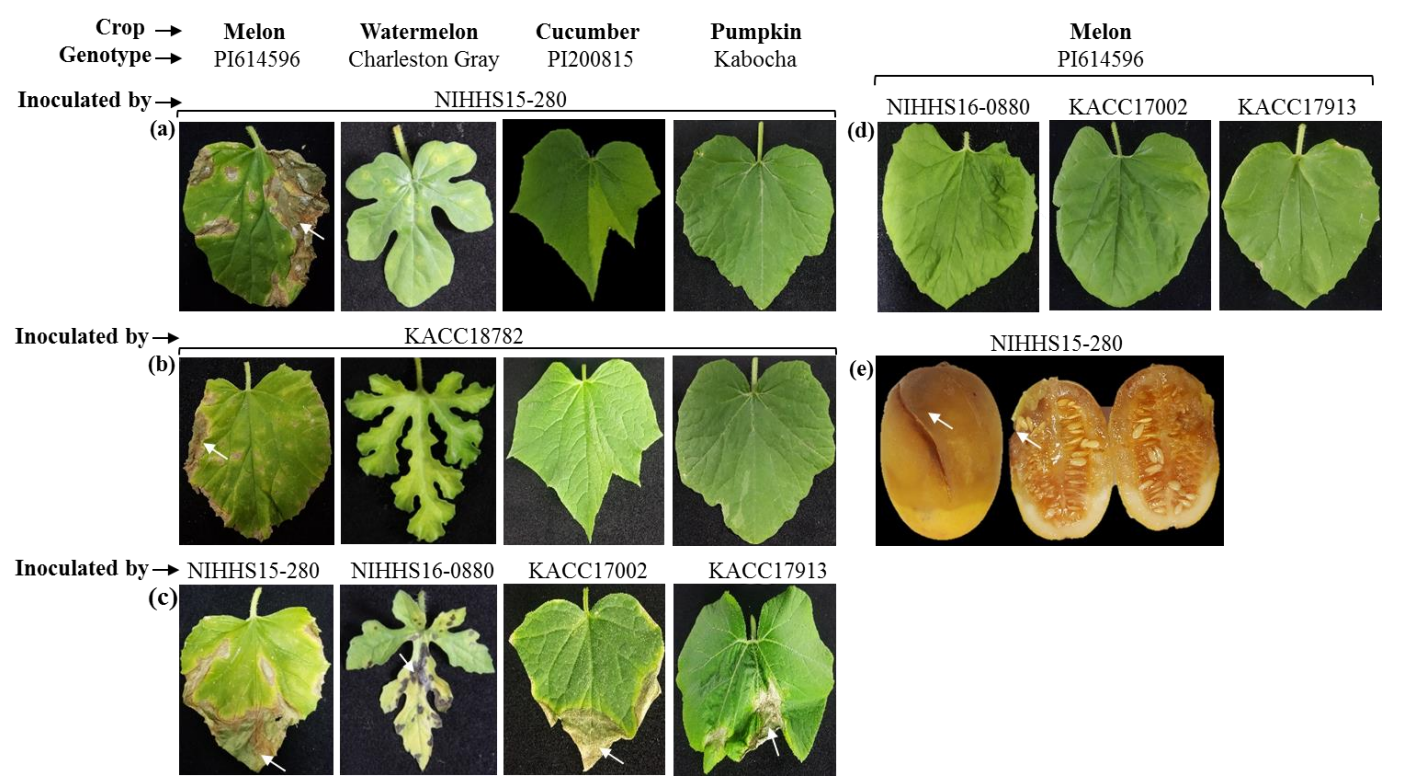

Figure 1. Melon, watermelon, cucumber, and pumpkin plants were inoculated with A. citrulli strains (a) NIHHS15-280, (b) KACC18782, (c) corresponding host, (d) melon with NIHHS16-088, KACC17002, and KACC17913 strains and (e) melon fruits with NIHHS15-280 strain. A. citrulli strains NIHHS15-280 and KACC18782 showing exclusively virulence towards melon leaves and fruits at 12 and 7 DAI respectively. Typical BFB symptoms are indicated by white arrows. All leaves and fruits were detached just before taking photographs. 
Typical BFB symptoms were observed in NIHHS15-280- and KACC18782-inoculated leaves of the susceptible melon genotype PI614596 at 12 days after inoculation (DAI), whereas no/mildly symptoms were visible on watermelon, cucumber, or pumpkin leaves (Figure 1a,b). When inoculated with their respective known virulent strains, NIHHS16-088, KACC17002, and KACC17913, typical BFB symptoms developed on watermelon, cucumber, and pumpkin genotypes, respectively (Figure 1c). Cross-inoculation of these strains on melon (PI614596) did not/mildly produce BFB symptoms (Figure 1d).

A. citrulli strain NIHHS15-280 also caused BFB symptoms on melon fruits at 7 DAI (Figure 1e). Overall, the appearance of typical BFB symptoms on melon leaves only, with no/somewhat visible disease symptoms on watermelon, pumpkin, or cucumber leaves, indicated that strains NIHHS15-280 and KACC18782 were highly virulent towards the melon.

\subsection{Whole-Genome Alignment Allows Design of Melon Host-Specific and A. citrulli Strain Specific Primers}

The genome sizes of the three "AcWM" strains (5.07516-5.35277 Mb) were slightly higher than that of the three " $A c \mathrm{M}$ " strains (4.82187-4.90344 Mb). However, the GC contents were similar among the three " $A c W M$ " strain and the two " $A c \mathrm{M}^{\prime}$ " strain (68.53-68.87\%) excluding DSM17060. In case of all $A$. citrulli number of contigs varied from 1 to 139 , number of $16 \mathrm{~S}$ rRNA gene is 4 to 5, Symmetric Identity (\%) also varied from 90.48 to 99.98 (apart from KACC17005) and Gapped Identity (\%) almost similar (not including KACC17005) (Table 2).

Table 2. Genomic information of $A$. citrulli strains used for whole-genome alignment.

\begin{tabular}{|c|c|c|c|c|c|c|c|c|c|c|}
\hline SI & Strain & HP & $\begin{array}{c}\text { GS } \\
(\mathrm{Mb})\end{array}$ & GC\% & Contigs & $\begin{array}{c}16 S \\
\text { rRNA }\end{array}$ & BioSample & SI (\%) & $\begin{array}{c}\text { GI } \\
(\%)\end{array}$ & References \\
\hline 1 & AAC00-1 & Watermelon & 5.35277 & 68.53 & 1 & 4 & SAMN02598334 & 99.80 & 99.98 & [54] \\
\hline 2 & KACC17005 & Watermelon & 5.34992 & 68.54 & 1 & 4 & SAMN07718226 & & & [55] \\
\hline 3 & Tw6 & Watermelon & 5.07516 & 68.70 & 24 & 5 & SAMN03268415 & 90.48 & 99.52 & [62] \\
\hline 4 & M6 & Melon & 4.82187 & 68.87 & 139 & 5 & SAMN04157986 & 91.36 & 99.63 & [50] \\
\hline 5 & pslb65 & Melon & 4.90344 & 68.80 & 24 & 5 & SAMN03333326 & 92.04 & 99.54 & [53] \\
\hline 6 & DSM 17060 & Melon & 4.84827 & & 71 & 5 & SAMN04489709 & 92.04 & 99.51 & [63] \\
\hline
\end{tabular}

N.B. The strains isolated from, and/or more virulent to, watermelon and melon hosts, are referred to as " $A c W M$ " and " $A c \mathrm{M}$ " respectively, throughout the manuscript; HP, GS, SI, and GI denotes Host Plant, Genome Size, Symmetric Identity, and Gapped Identity, respectively.

The whole-genome alignment of these bacterial strains revealed that most nucleotide sequences are conserved; along with multiple rearrangements were observed among these pathogenic strains (Figure 2a-d). 
(a)
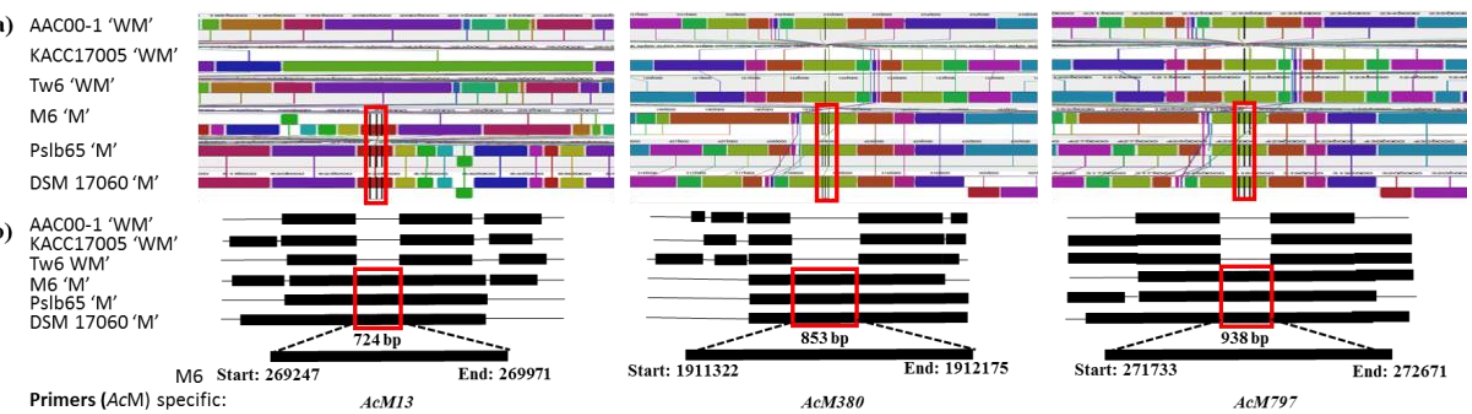

(c) $\mathrm{AACOO}-1 \mathrm{~W} \mathrm{WM}$ KACC17005 'WM' Tw6 'WM' $M 6$ ' $M$ ' Pslb65 'M' DSM 17060 ' $M$ ' (d) AACOO-1 ' $W M^{\prime}$ ' Tw6 WM' M6 ' $M$ ' DSM 17060 'M'
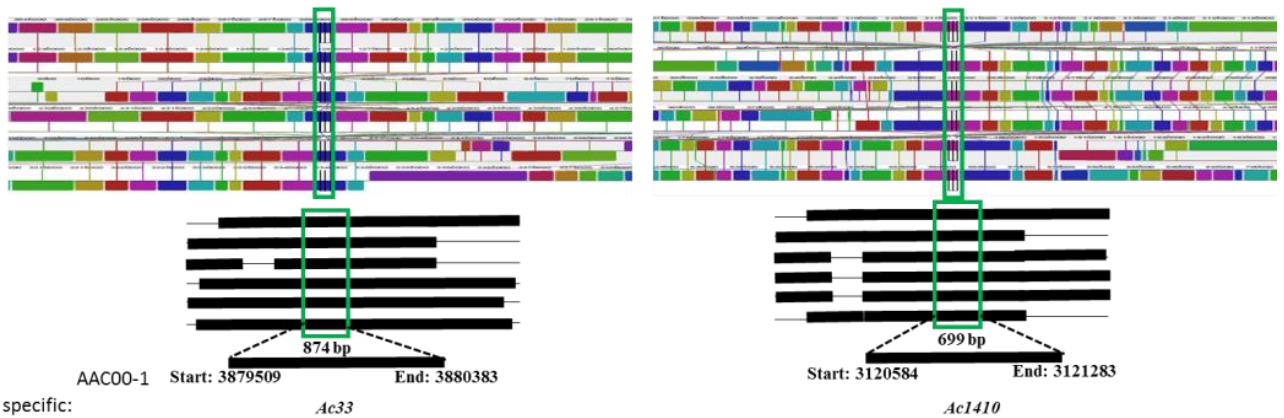

Primers (A. citrulli) specific:

$$
\text { Ac1410 }
$$

Figure 2. Segments of whole-genome alignment of six A. citrulli strains. Primers AcM13, AcM380, and $A c M 797$ were designed from the M6 strain where three segments (red rectangles) that are present only in "AcM" strains (a,b). A. citrulli specific-primers Ac33 and Ac1410 were designed from the AAC001 strain where two segments (green rectangles) that are present in both "AcWM" and "AcM" strains (c,d). Details of the primers are shown in Table 3. In the Mauve alignment (Mauve tool, version 2.4.0), each genome is laid out horizontally with homologous segments (LCBs) outlined as colored rectangles. Lines collate aligned segments among genomes. Average sequence similarities within an LCBs, measured in sliding windows, are proportional to the heights of interior colored bars. Large Sections of white within blocks and gaps between blocks indicate lineage-specific sequences. Right side in strains name WM and M indicate A. citrulli strains isolated from watermelon and melon hosts, respectively.

Table 3. Primer sets designed for detecting A. citrulli strains causing BFB disease via polymerase chain reaction $(\mathrm{PCR})$ assays.

\begin{tabular}{|c|c|c|c|c|c|c|}
\hline $\begin{array}{l}\text { Primer } \\
\text { Name }\end{array}$ & Primer Sequence & LCB & Genomic Location & Gene Description & $\begin{array}{l}\text { Amplicon } \\
\text { Size (bp) }\end{array}$ & $\begin{array}{l}\text { Annealing } \\
\text { Condition }\end{array}$ \\
\hline AcM13 & $\begin{array}{l}\text { F: TCGCGGGCCGTGATGTTCCG } \\
\text { R: TGGACTTCGGGTGGGCCTTCA }\end{array}$ & 13 & (+) 269247 to 269971 & Glycosyl hydrolase & 724 & \multirow{2}{*}{$\begin{array}{l}65^{\circ} \mathrm{C} \\
\text { for } 45 \mathrm{~s}\end{array}$} \\
\hline AcM380 & $\begin{array}{l}\text { F: GCATCCGGTGTGCTGCTGGA } \\
\text { R: GAGATGTCAGAGTCGCACGGT }\end{array}$ & 380 & (+) 1911322 to 1912175 & ATP-binding protein & 853 & \\
\hline AcM797 & $\begin{array}{l}\text { F: AAGGCGGACATGGGTTGGCT } \\
\text { R: CTGCGCCTGCGCCCACACCA }\end{array}$ & 797 & (+) 271733 to 272671 & $\begin{array}{l}\text { Twin-arginine translocation } \\
\text { pathway signal }\end{array}$ & 938 & \multirow{3}{*}{$\begin{array}{l}63^{\circ} \mathrm{C} \\
\text { for } 30 \mathrm{~s}\end{array}$} \\
\hline Ac33 & $\begin{array}{l}\text { F: TCGATAAGGCCACCAAGTTC } \\
\text { R: GACTGGGGTAACGTGGGGCT }\end{array}$ & 33 & (-) 3879509 to 3880383 & $\begin{array}{l}\text { Hypothetical protein } \\
\text { phosphatase }\end{array}$ & 874 & \\
\hline Ac1410 & $\begin{array}{l}\text { F: TAGCGCAGCCCCACCCAGTG } \\
\text { R: CAAGGGCGACAAGATGATGT }\end{array}$ & 1410 & (+) 3120584 to 3121283 & Sugar-binding protein & 699 & \\
\hline
\end{tabular}

AcM13, AcM380, and AcM797 were designed from the genome sequence of A. citrulli strain M6 that is only present in " $(A c \mathrm{M})$ " and Ac33 and Ac1410 were designed from the A. citrulli strain AAC001, which is present in all A. citrulli strains; LCB, local colonial block; +/-, positive/negative strand; F and R, forward and reverse primers, respectively.

The whole-genome alignment facilitated the identification of genomic fragments that are present only in "AcM". Three sets of primers, AcM13, AcM380, and AcM797, were designed from the three "AcM" strains specific on local colonial blocks (LCB) of LCB13, LCB380, and LCB797, respectively. These primers were expected to produce 724, 853- and 938-bp amplicons, respectively, from " $A c \mathrm{M}^{\text {" }}$ strains (Figure 2a,b and Table 3). In addition, two sets of primers, Ac33 and Ac1410, were designed from on LCBs of LCB33 and LCB1410, which were common to A. citrulli strains specific. These primers 
were expected to amplify 874 and 699-bp genomic fragments from all six A. citrulli strains, irrespective of their association with melon or watermelon hosts (Figure 2c,d and Table 3).

\subsection{PCR-Based Assays Show Specificity of Primers}

Three primer sets AcM13, AcM380, and AcM797, designed for detecting "AcM" strains, produced the anticipated PCR amplicons of 724, 853, and 938-bp, respectively, for both the NIHHS15-280 and KACC18782 strains that were highly virulent towards melon (Figure 3a). A. citrulli strains that were associated with additional cucurbit (such as watermelon, cucumber, and pumpkin) and other bacterial strains such as Acidovorax avenae subsp. avenae (KACC16207), Pseudomonas syringae pathovar. maculicola (ICMP13051), and the fungal species Didymella bryoniae (NIHHS1326) were not amplified (Figure 3a) by these "AcM" strain-specific primers. Two A. citrulli strain specific-primers Ac33 and Ac1410 designed for detecting A. citrulli strains, irrespective of their host, detected all target $A$. citrulli strains but not the other bacterial and fungal strains (Figure $3 b$ ).

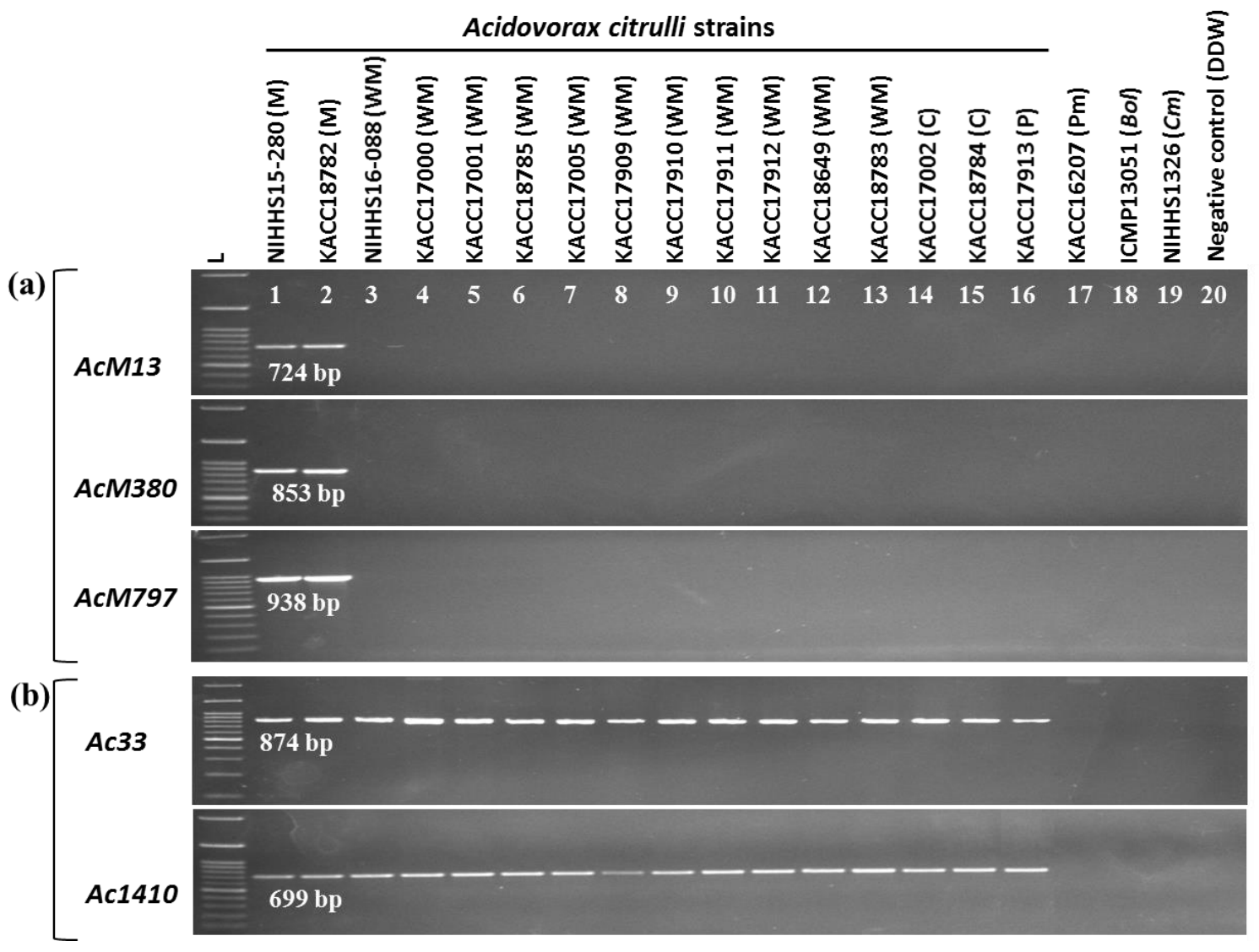

Figure 3. Agarose gel electrophoresis of polymerase chain reaction (PCR) products from gDNA of A. citrulli strains, other bacterial strains, and a fungal isolate using the primers designed based on whole-genome alignment. PCR using "AcM" strain-specific primers AcM13, AcM380, and AcM797 (a) and $A$. citrulli strain-specific primers $A c 33$ and $A c 1140$ (b). gDNA $(\sim 50 \mathrm{ng} / \mu \mathrm{L})$ of the bacterial strains was used as template. A. citrulli strains-specific primers Ac33 and Ac1410 were used as controls to check the PCR amplification of the bacterial DNA. Strains followed by the letters M, WM, P, C, Pm, $\mathrm{Bol}$, and $\mathrm{Cm}$ indicate pathogenic strains reported to be collected from melon, watermelon, pumpkin, cucumber, proso-millet, Brassica oleracea var. capitata, and Cucumis melo hosts, respectively. Non- $A$. citrulli strains such as KACC16207 (Acidovorax avenae subsp. Avenae), ICMP13051 (Pseudomonas syringae pv. maculicola) and a fungal isolate NIHHS1326 (Didymella bryoniae), as well as DDW, were used as negative controls. Lane L indicates a HIQ 100 bp plus DNA Ladder Mix (BIONEER, Korea) used as a size marker. 


\subsection{Bio-PCR Shows Sensitivity of the Primers}

The sensitivity of the developed primers for detection of " $A c \mathrm{M}$ " strains from artificially infected samples was tested using Bio-PCR. Primer sets AcM13, AcM380, and AcM797 successfully produced amplicons of the predictable sizes from leaf (Figure $4 a$ ) and fruit/seed (Figure $4 b$ ) washing suspensions of melon infected with NIHHS15-280 strain. No amplification was observed for leaf washings of watermelon, cucumber or pumpkin (Figure 4a), in agreement with the lack of observed disease symptoms (Figure 1a). However, when inoculated with their respective virulent $A$. citrulli strains, conspicuous BFB symptoms were visible on watermelon, cucumber, and pumpkin leaves, and the bacteria were successfully detected by A. citrulli specific-primer sets Ac33 and Ac1410 in the Bio-PCR assay (Figure 4c).

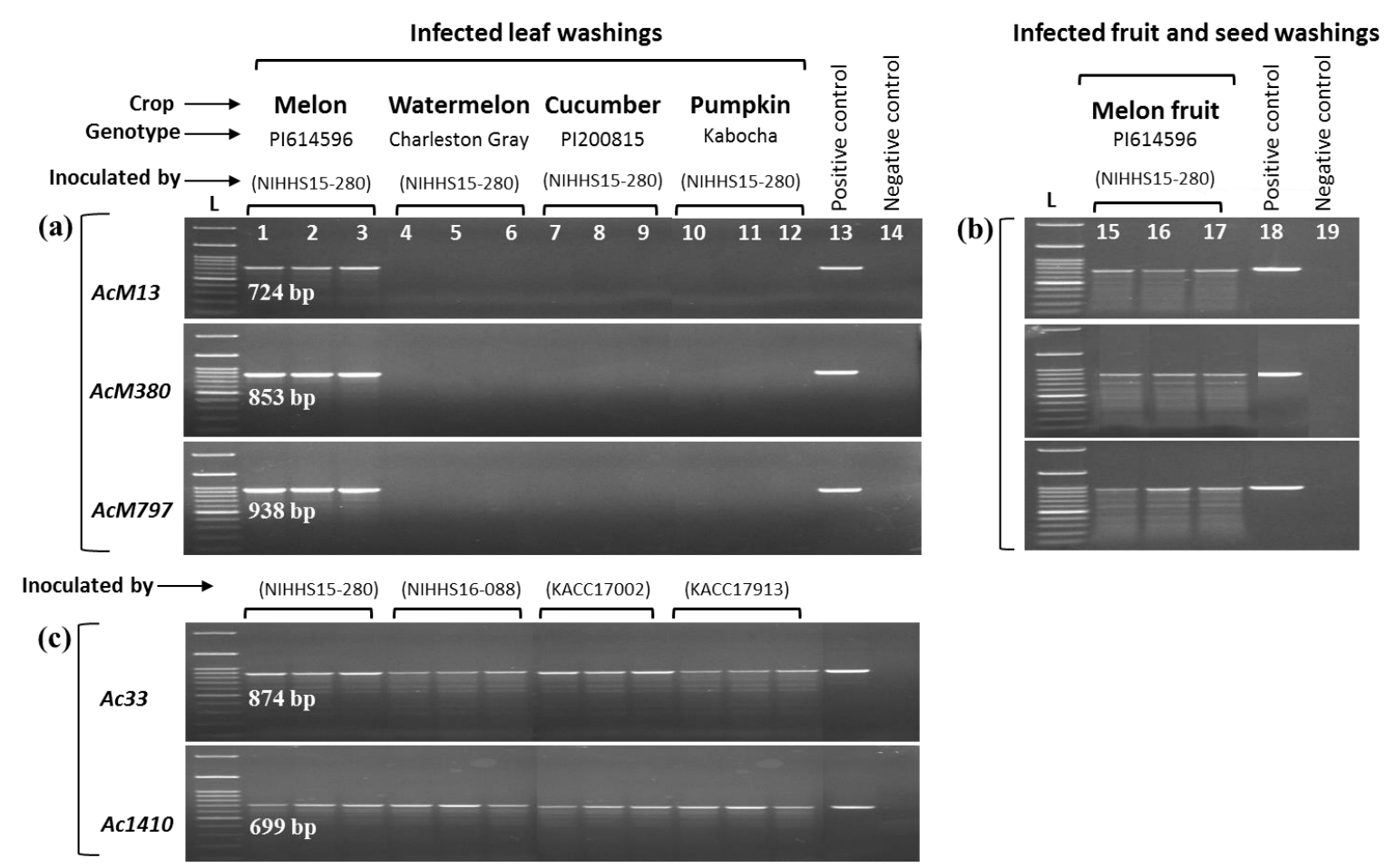

Figure 4. Bio-PCR detection of $A$. citrulli from the artificially infected leaf, fruit and seed washings using the primers designed based on whole-genome alignment. (a) Artificially infected (inoculated with NIHHS15-280) leaf and (b) fruit/seed washings were used as PCR templates for the " $A c \mathrm{M}$ " strain-specific primer sets AcM13, AcM380 and AcM797. A. citrulli-strain specific primer sets Ac33 and Ac1410 detected all $A$. citrulli strains from the leaf washings of melon, watermelon, cucumber, and pumpkin infected by the virulent strains NIHHS15-280, NIHHS16-088, KACC17002, and KACC17913, respectively (c). Three independent samples for each crop-strain combination were assessed. gDNA of A. citrulli strain NIHHS15-280 (lanes 13,18) and double distilled water (lanes 14, 19) were used as positive and negative controls, respectively. HIQ 100 bp plus DNA Ladder Mix (BIONEER) was used as a size marker (lane L). Details of the inoculation procedure are described in Section 4.5, and collection of leaf washings and Bio-PCR procedures are described in Section 4.7.

\subsection{Detection Limits of the PCR Assays}

The minimum DNA concentration of $A$. citrulli strains required for PCR detection using our primers was determined with a 10-fold dilution series, ranging from $65 \mathrm{ng} / \mu \mathrm{L}$ to $6.5 \times 10^{-3} \mathrm{ng} / \mu \mathrm{L}$, of gDNA of $A$. citrulli NIHHS15-280.The minimum detection limits of all strain-specific primer sets i.e. "AcM" (AcM13, AcM380, and AcM797) and "AcWM" (Ac33 and Ac1410) are $6.5 \times 10^{-3} \mathrm{ng} / \mu \mathrm{L}$ gDNA of $A$. citrulli strain NIHHS15-280 (Figure 5a,b). These results were achieved using 25 cycles 
of PCR amplification of $1 \mu \mathrm{L}$ of each series diluted bacterial gDNA following the condition mention in Section 4.5.

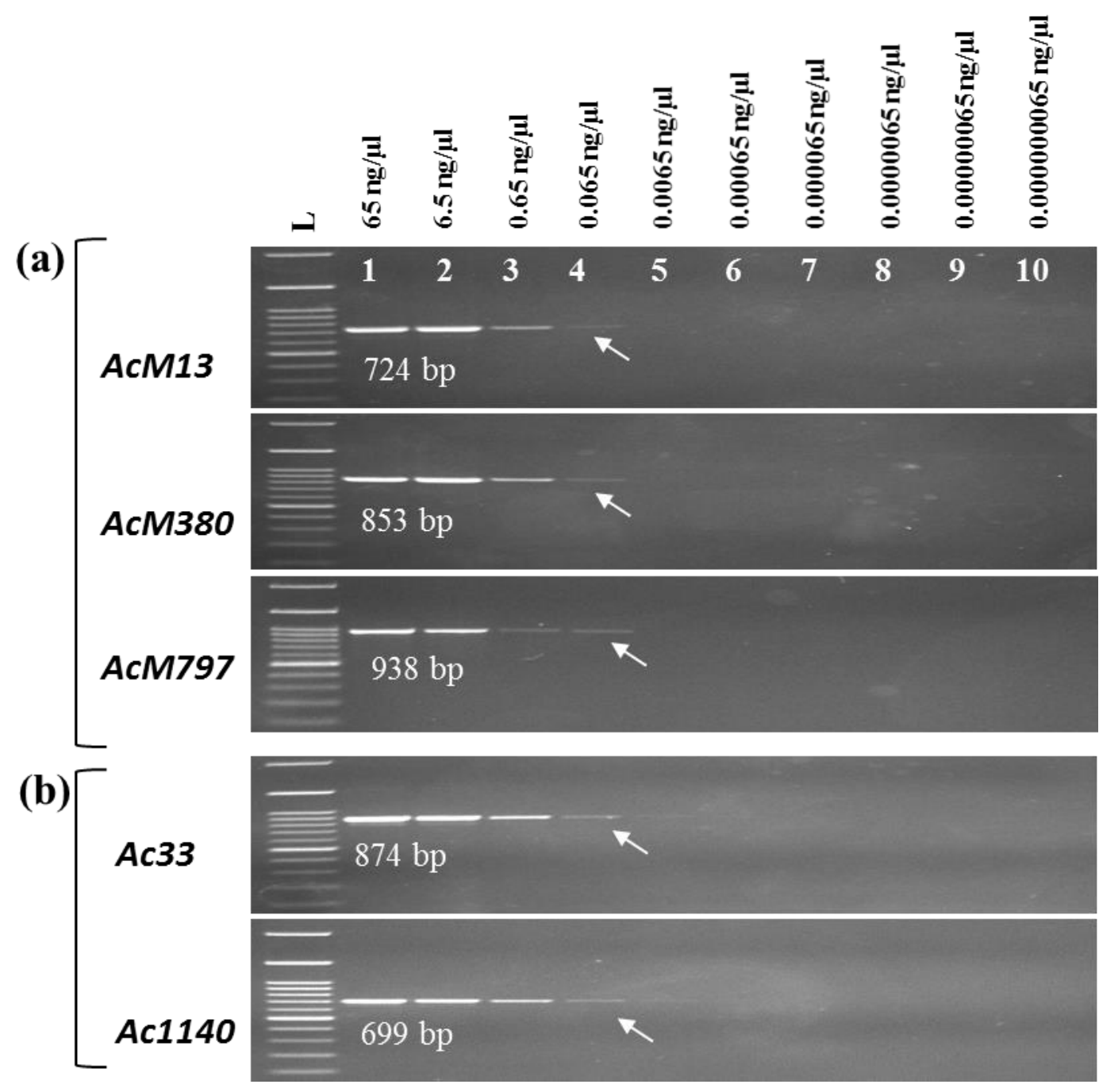

Figure 5. DNA detection limits of the PCR assays. Detection limit of gDNA of A. citrulli strain using "AcM" strain-specific primer sets (a) AcM13, AcM380, and AcM797 and (b) A. citrulli strain-specific primer sets Ac33 and Ac1410 in PCR assays. Lanes 1 to 10,10-fold dilution series of gDNA of $A$. citrulli strain NIHHS15-280 starting from $65 \mathrm{ng} / \mathrm{\mu L}$; Lane L contains HIQ 100 bp plus DNA Ladder Mix (BIONEER, Republic of Korea) as a size marker.

\section{Discussion}

The development of efficient diagnostic tools for bacterial fruit blotch-causing A. citrulli strains has been the subject of intense investigation over the past few decades. Substantial population diversity exists among strains of $A$. citrulli, and strains are known to show differential virulence towards various cucurbit hosts $[5,23,33,45,50,61,64]$. Based on this differential virulence, DNA finger-printing and biochemical properties have characterized two major groups of $A$. citrulli, with group II strains being predominantly isolated from watermelon hosts, while group I strains are associated with non-watermelon hosts [35]. Each strain shows aggressive virulence to its corresponding hosts $[45,65]$. This defined group II strains are more virulent towards watermelon. The differential virulence of group I strains to various non-watermelon cucurbit hosts, such as melon, cucumber, pumpkin, and gourds, is yet to be clearly characterized. This is particularly important, as reports of host range expansion, 
global spread, and increasing virulence of the pathogen suggest that $A$. citrulli strains of group I could also be differentially virulent to various non-watermelon cucurbit crops $[4,23,66]$.

Among non-watermelon cucurbit crops, melon production is known to be greatly affected by BFB. After watermelon, melon is an important fruit crop, with 26 million tons of melons produced global in 2009 (http://faostat.fao.org). There are reports of many A. citrulli strains isolated from melon hosts $[5,52,61,64,67-69]$. However, it is not known if these strains are specifically virulent towards melon or more virulent towards them. Our cross-inoculation assay with two such strains, NIHHS15-280 and KACC18782, on melon, watermelon, cucumber, and pumpkin revealed that these two strains are highly virulent towards melon (Figure 1). We then developed PCR-based markers for detecting such melon host-associated $A$. citrulli strains.

Various techniques have been used for detecting A. citrulli strains, as discussed in Section 1. In general, PCR-based techniques are particularly advantageous as they detect strains based on inherent gDNA and are thus sensitive and specific towards the target strains only [42,50,51]. Most of the PCR-based A. citrulli strain-specific markers were developed by targeting specific genes, such as $16 \mathrm{~S}$ rDNA [48], 16S-23S ITS regions of rDNA [26,28,70], YD-repeat protein [44], BOX fragments [58,67], and hrp gene sequences [71,72]. These genes are highly conserved among the members of a particular bacterial species and thus are successful in distinguishing $A$. citrulli strains from other bacterial species [42,45,57-60]. However, when it comes to distinguishing closely related members of the same species, for example in our case, detecting A. citrulli strains that are more virulent towards melon hosts, primers need to be designed from genomic regions that exist only in the target strains.

The availability of whole-genome sequences of an increasing number of bacterial strains (mainly due to the advances and affordability in genome sequencing technologies) and the development of comprehensive suites of sequence analytical tools offers new opportunities in identifying strain-specific genomic regions by comparing the whole genomes of closely related bacterial strains. Such approaches have been successfully used for developing race- and pathovar-specific molecular markers for Xanthomonas campestris pv. campestris [73-75], Xanthomonas euvesicatoria [76], Cordyceps militaris [77], and Plasmodiophora brassicae [78]. In the case of A. citrulli, Eckshtain-Levi et al. [50] successfully used this comparative genomic approach to identify eight genomic fragments that are only present in model group II A. citrulli strain AAC00-1 and absent in model group I A. citrulli strain M6.

We compared whole-genome sequences of three A. citrulli strains M6, pslb65, and DSM 17060, that were isolated from melon with three A. citrulli strains AAC00-1, KACC17005, and Tw6, that were isolated from watermelon (Table 1 and Figure 2) to identify differential genomic regions. Three genomes of each bacterial group were used to ensure the identification of robust strain-specific differential genomic regions. Three sets of primers, AcM13, AcM380, and AcM797, were designed from the unique genomic fragments hosting genes encoding glycosyl hydrolase, ATP-binding protein, and twin-arginine

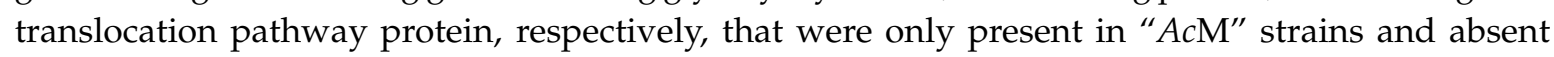
in "AcWM" strains (Table 3). The ATP-binding proteins are essential for cell viability, virulence, and pathogenicity $[79,80]$, and twin-arginine translocation pathway proteins are known to be very important for bacterial virulence [81-83]. The glycosyl hydrolases are known to play roles in bacterial pathogenesis in mammals, especially by producing enzymes that can modify the carbohydrates of host defense mechanisms to favor bacterial survival and persistence [84-86]. However, the exact role of glycosyl hydrolases in phytopathogenic bacteria is yet to be known [85].

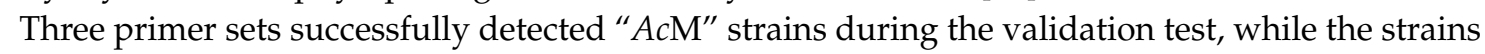
associated with other cucurbit hosts such as watermelon, cucumber, and pumpkin and strains of other bacterial species were not. These primers also detected the A. citrulli strains (melon host) from artificially infected leaf, fruit and seed washing suspensions in a Bio-PCR assay, which does not require the isolation of bacterial DNA. The ability to detect bacteria from a very low concentration of template DNA further indicated the high sensitivity of the developed markers. However, the efficacy of the developed markers should be further validated using a wider range of $A$. citrulli strains associated with different cucurbit hosts. 


\section{Materials and Methods}

\subsection{Retrieval and Alignment of Whole Genomes of A. citrulli Strains}

Whole-genome sequences of three A. citrulli strains M6, Pslb65, and DSM 17060 that were isolated from melon hosts and three A. citrulli strains AAC00-1, KACC17005, and tw6 that were isolated from watermelon hosts (referred to as "AcM" and "AcWM" strains respectively, throughout the manuscript) were retrieved from the National Center for Biotechnology Information database (https://www.ncbi.nlm.nih.gov/). The details of these strains are given in Table 1. The whole-genome sequences were aligned using the multiple sequence alignment tools Mauve, version v.2.4.0 (http://darlinglab.org/mauve/download.html), and Geneious (14 days free trial version; https://www.geneious.com/free-trial/) (Figure 2) with default parameters to identify common and unique genomic fragments between $A$. citrulli strains associated with melon and watermelon hosts.

\subsection{Design of Primers for Detection of A. citrulli Strains}

Three pairs of primers (AcM13, AcM380, and AcM797) for detecting A. citrulli strains associated with melon hosts were designed from three segments $(269,247-269,971 \mathrm{bp}, 1,911,322-1,912,175 \mathrm{bp}$, and 271,733-272,671 bp) in the M6 strain (marked as red rectangles in Figure 2a,b), respectively, that are only present in "AcM" strains (Figure 2a,b). In addition, two sets of $A$. citrulli specific-primers (Ac33 and Ac1410) were designed from the segments 3,879,509-3,880,383 bp and 3,120,584-3,121,283 bp in the AAC00-1 strain (green rectangles in Figure 2c,d), respectively, that are present in both " $A c \mathrm{M}$ " and "AcWM" strains (Figure 2c,d). Primers were designed using Primer3 software (http://www.bioinformatics.nl/cgi-bin/primer3plus/primer3plus.cgi), and in silico specificity testing was done using the "in silico simulation of molecular biology experiments" tool accessible from http://insilico.ehu.eus/. The details of the primers along with amplicon size, associated genes, and PCR conditions are given in Table 3.

\subsection{Bacterial Strains, Growing Conditions, and Inoculum Preparation}

Nineteen bacterial strains belonging to three different genera, Acidovorax, Pseudomonas, and Didymella, were collected from various sources for this study. The details of the strains along with their hosts and collection source are given in Table 1. All bacteria were cultured on King's B (KB) media supplemented with $100 \mu \mathrm{g} \cdot \mathrm{mL}^{-1}$ ampicillin for 36 to $48 \mathrm{~h}$ at $28^{\circ} \mathrm{C}$ until formation of bacterial colonies. All bacterial suspensions were prepared by inundating the culture plates with $5 \mathrm{~mL}$ of sterile, double-distilled water (DDW) and gently scraping off the bacterial colonies using a sterile L-shaped rubber spreader. For inoculation, bacterial suspensions were diluted to a final concentration of $\sim 3 \times$ $10^{6}$ colony-forming units (cfu) $\mathrm{mL}^{-1}$.

\subsection{Extraction of Bacterial Genomic DNA}

Genomic DNA (gDNA) from all bacterial strains was extracted using a DNeasy Plant Mini Kit (Qiagen, Hilden, Germany) following the manufacturer's instructions. The amount and quality of the extracted DNA was then measured using a Nanodrop ND-1000 spectrophotometer (Nano Drop, Wilmington, DE, USA).

\subsection{Specificity of Primers in PCR Assays}

The specificity of the three "AcM" strains-specific primers, AcM13, AcM380, and AcM797, and two A. citrulli strain-specific primers, $A c 33$ and $A c 1410$, was assessed in a PCR assay using gDNA from the target melon host $A$. citrulli strains NIHHS15-280 and KACC18782, along with other cucurbit host-specific $A$. citrulli strains and other bacterial strains. PCR was performed in a $20-\mu \mathrm{L}$ reaction mixture containing $9 \mu \mathrm{L}$ of Emerald PCR master mix (Takara, Shiga, Japan), $1 \mu \mathrm{L}$ each of forward and reverse primer (10 picomole), $8 \mu \mathrm{L}$ of ultrapure water, and $1 \mu \mathrm{L}$ of bacterial gDNA $(\sim 50 \mathrm{ng} / \mu \mathrm{L})$. 
PCR was performed in a thermocycler (Takara) using the following conditions: initial denaturation at $95{ }^{\circ} \mathrm{C}$ for $5 \mathrm{~min}$ followed by 25 cycles of denaturation at $95^{\circ} \mathrm{C}$ for $30 \mathrm{~s}$, annealing at $65^{\circ} \mathrm{C}$ for $45 \mathrm{~s}$ (for "AcM" strain-specific primers AcM13, AcM380, and AcM797) or $63^{\circ} \mathrm{C}$ for $30 \mathrm{~s}$ (for A. citrulli strain-specific primers $A c 33$ and $A c 1410$ ), then $72{ }^{\circ} \mathrm{C}$ for $40 \mathrm{~s}$, and a final elongation at $72{ }^{\circ} \mathrm{C}$ for $5 \mathrm{~min}$ (Table 3). Electrophoresis was performed using a 1.2\% agarose gel stained with blue mango (BioD, Gwangmyeong, Korea) in TAE buffer at $100 \mathrm{~V}$ for $40 \mathrm{~min}$ and visualized on an ENDURO ${ }^{\mathrm{TM}}$ GDS gel documentation system under UV radiation $(350 \mathrm{~nm})$. A. citrulli strain-specific primers Ac33 and Ac1410 were used as positive controls to identify any potential false-positive results. DDW was used as a negative control. HIQ 100 bp plus DNA Ladder Mix (BIONEER) was used as a size marker.

\subsection{Pathogenicity Test of Bacterial Strains Using Cross Inoculation Assay}

Susceptible cultivars of melon (PI614596) [87], watermelon (Charleston Gray) [88], cucumber (PI200815), and pumpkin (Kabocha) were grown in 32-celled trays containing artificial soil mix in a controlled plant growth chamber at $25 \pm 2{ }^{\circ} \mathrm{C}$, with a 16-h day length and $440 \mu \mathrm{moles} / \mathrm{m}^{2} / \mathrm{s} \mathrm{light}$ intensity at the bench level in a glasshouse. Five-week-old plants were inoculated with a concentration of $\sim 3 \times 10^{6}$ (cfu) $\mathrm{mL}^{-1}$ [22] with A. citrulli strains NIHHS15-280 and KACC18782 (collected from melon hosts, as per the records of Korean Agriculture Culture Collection (KACC) and NIHHS), as shown in Figure 1a,b. These genotypes were also inoculated with corresponding A. citrulli strains NIHHS16-088, KACC17002, and KACC17913 that are virulent to watermelon, cucumber, and pumpkin, respectively (Figure 1c). Furthermore, melon (PI614596) lines again inoculated with A. citrulli strains NIHHS16-088, KACC17002 and KACC17913 that are virulent to watermelon, cucumber \& pumpkin, respectively (Figure 1d). In addition, mature detached fruits of melon were inoculated by injecting $1 \mathrm{ml}$ of bacterial suspension at $1 \times 10^{8} \mathrm{cfu} / \mathrm{mL}$ [23] through the rind with a 5-ml syringe, at a depth of no more than $1 \mathrm{~cm}$, in two different sites per fruit with A. citrulli strain NIHHS15-280. Inoculated fruits were placed in plastic boxes (one fruit/box) and incubated at 25 to $28^{\circ} \mathrm{C}$. Disease symptoms on both leaves and fruits were recorded at 12 and 7 DAI, respectively. The leaves, fruit and seed washing suspensions were used as template DNA for detection of $A$. citrulli strains causing BFB on melon by the developed markers in a Bio-PCR-based assay, as described in Section 4.7. The experimental design was completely randomized with three replicates (plants) per genotype, with three leaves and fruits assessed per replicate.

\subsection{Bio-PCR Assay}

For the Bio-PCR assay, infected leaf, fruit and seeds washings (of samples from the cross-inoculation assay as shown in Figure 1) were used as template DNA. Small, dark-brown, water-soaked, visible lesions of about $2 \mathrm{~cm}$ were cut into small pieces using a sterile scalpel and immersed in $500 \mu \mathrm{L}$ of sterile distilled water in a 1.5-mL tube for $40 \mathrm{~min}$ (with occasional shaking). Thereafter, $10 \mu \mathrm{L}$ of washing suspension (containing bacterial cells) was collected for the Bio-PCR reaction. The Bio-PCR assay was performed using the "AcM" strain-specific primers AcM13, AcM380, and AcM797 and A. citrulli strain-specific primers Ac33 and Ac1410 using the same PCR conditions as described in Section 4.5, except that the number of amplification cycles was 30. Increasing the number of PCR cycles may detect target strains at an even lower concentration of template DNA.

\subsection{Detection Limit of Bacterial DNA in the PCR Assay}

The minimum gDNA concentration of $A$. citrulli strains detected by the developed primers in the PCR assay was determined using a 10-fold dilution series (from 65 to $6.5 \times 10^{-4} \mathrm{ng} / \mu \mathrm{L}$ ) of the gDNA of A. citrulli strain NIHHS15-280. One microliter of each dilution was used directly as the template DNA with PCR conditions as described in Section 4.5. 


\section{Conclusions}

This study exploited the variation within the whole-genome sequences of $A$. citrulli strains to develop PCR-based markers for detecting A. citrulli strains that are associated with melon hosts. This is the first report of PCR-based markers that can be used for direct, sensitive, and rapid detection of the A. citrulli strains that cause BFB disease, particularly in melon. These markers have the potential to detect melon host $A$. citrulli strains from asymptomatic fields prior to the appearance of symptoms, allowing farmers to enact timely control measures. The markers could also allow seed health testing prior to planting and ensure transboundary movement of disease-free seeds for quarantine purposes.

Author Contributions: M.R.I. prepared and cultured the samples, DNA extraction, performed wet lab experiments, analyzed the data, interpreted the results, and wrote the first draft of the manuscript. M.R.I. and D.M.I.J. conducted the in silico analysis. M.R.I. and M.R.H. designed the study. M.A. and H.-J.J. assisted in bacterial culture, sample preparation and PCR assays. M.R.H. comprehensively revised and finalized the manuscript. I.-S.N., H.-T.K. and J.-I.P. conceived and supervised the project. All authors read and approved the final draft of the manuscript.

Funding: This study was supported by the Golden Seed Project (Grant No. 213007-05-3-CG100) of the Ministry of Agriculture, Food and Rural Affairs (MAFRA), Republic of Korea.

Acknowledgments: We thank the Korean Agricultural Culture Collection, Korea; National Institute of Horticultural and Herbal Science, Korea and the ICMP collection from New Zealand for providing bacterial strains.

Conflicts of Interest: The authors declare no conflict of interest.

\section{References}

1. Schaad, N.W.; Postnikova, E.; Sechler, A.; Claflin, L.E.; Vidaver, A.K.; Jones, J.B.; Agarkova, I.; Ignatov, A.; Dickstein, E.; Ramundo, B.A. Reclassification of subspecies of Acidovorax avenae as A. Avenae (Manns 1905) emend., A. cattleyae (Pavarino, 1911) comb. nov., A. citrulli Schaad et al., 1978) comb. nov., and proposal of A. oryzae sp. nov. Syst. Appl. Microbiol. 2008, 31, 434-446. [CrossRef] [PubMed]

2. Webb, R.; Goth, R. A seedborne bacterium isolated from watermelon. Plant Dis. Report. 1965, 49, 818-821.

3. Bahar, O.; Burdman, S. Bacterial fruit blotch: a threat to the cucurbit industry. Isr. J. Plant Sci. 2010, 58, $19-31$. [CrossRef]

4. Burdman, S.; Walcott, R. Acidovorax citrulli: Generating basic and applied knowledge to tackle a global threat to the cucurbit industry. Mol. Plant Pathol. 2012, 13, 805-815. [CrossRef] [PubMed]

5. Silva, G.M.; Souza, R.M.; Yan, L.; Júnior, R.S.; Medeiros, F.H.; Walcott, R.R. Strains of the group I lineage of Acidovorax citrulli, the causal agent of bacterial fruit blotch of cucurbitaceous crops, are predominant in Brazil. Phytopathology 2016, 106, 1486-1494. [CrossRef] [PubMed]

6. Wall, G.; Santos, V. A new bacterial disease on watermelon in the Mariana Islands. Phytopathology 1988, 78, $1-9$.

7. Schaad, N.W.; Sowell, G.; Goth, R.W.; Colwell, R.R.; Webb, R.E. Pseudomonas pseudoalcaligenes subsp. citrulli subsp. nov. Int. J. Syst. Evol. Micr. 1978, 28, 117-125. [CrossRef]

8. Latin, R.; Rane, K. Bacterial fruit blotch of watermelon in Indiana. Plant Dis. 1990, 74. [CrossRef]

9. Schaad, N.; Postnikova, E.; Randhawa, P. Emergence of Acidovorax avenae subsp. citrulli as a crop threatening disease of watermelon and melon. In Pseudomonas syringae and Related Pathogens; Iacobellis, N.S., Collmer, A., Hutcheson, S.W., Mansfield, J.W., Morris, C.E., Murillo, J., Schaad, N.W., Stead, D.E., Surico, G., Eds.; Springer: Dordrecht, The Netherlands, 2003; pp. 573-581.

10. Somodi, G.C.; Jones, J.; Hopkins, D.; Stall, R.; Kucharek, T.; Hodge, N.; Watterson, J. Occurrence of a bacterial watermelon fruit blotch in Florida. Plant Dis. 1991, 75, 1053-1056. [CrossRef]

11. Hopkins, D. The Hypothetical Exam Question Becomes Reality. Plant Dis. 1995, 79, 761-765.

12. Isakeit, T.; Black, M.; Barnes, L.; Jones, J. First report of infection of honeydew with Acidovorax avenae subsp. citrulli. Plant Dis. 1997, 81, 694. [CrossRef] [PubMed]

13. Langston, D., Jr.; Walcott, R.; Gitaitis, R.; Sanders, F., Jr. First report of a fruit rot of pumpkin caused by Acidivorax avenae subsp. citrulli in Georgia. Plant Dis. 1999, 83, 199. [CrossRef] [PubMed]

14. Martin, H.; Horlock, C. First report of Acidovorax avenae subsp. citrulli as a pathogen of Gramma in Australia. Plant Dis. 2002, 86, 1406. [CrossRef] [PubMed] 
15. Martin, H.; O’Brien, R.; Abbott, D. First report of Acidovorax avenae subsp. citrulli as a pathogen of cucumber. Plant Dis. 1999, 83, 965. [CrossRef] [PubMed]

16. Xie, G.-L.; Zhang, G.-Q.; Liu, H.; Lou, M.-M.; Tian, W.-X.; Li, B.; Zhou, X.-P.; Zhu, B.; Jin, G.-L. Genome sequence of the rice-pathogenic bacterium Acidovorax avenae subsp. avenae RS-1. J. Bacteriol. 2011, 193, 5013-5014. [CrossRef]

17. Sowell, G., Jr. A bacterial disease causing severe damage to susceptible plant introductions of muskmelon [Cucumis melo]. Plant Dis. (USA) 1981. [CrossRef]

18. Conceição, C.S.; Felix, K.C.S.; Mariano, R.L.; Medeiros, E.V.; Souza, E.B. Combined effect of yeast and silicon on the control of bacterial fruit blotch in melon. Sci. Hortic. 2014, 174, 164-170. [CrossRef]

19. De Melo, E.A.; Rosa de Lima, R.M.; Laranjeira, D.; dos Santos, L.A.; de Omena Gusmão, L.; de Souza, E.B. Efficacy of yeast in the biocontrol of bacterial fruit blotch in melon plants. Trop. Plant Pathol. 2015, 40, 56-64. [CrossRef]

20. Sales Júnior, R.; Menezes, J. Mapeamento das doenças fúngicas, bacterianas e viróticas do cultivo do melão no Estado do RN. Mossoró. Escola Superior de Agricultura de Mossoró 2001.

21. Noh, J.; Kim, J.-H.; Lim, J.H.; Kim, T.B.; Seong, M.H.; Jung, G.T.; Kim, J.M.; Cheong, S.-S.; Oh, N.K.; Lee, W.-H. Occurrence of diseases and case of clinical diagnosis on watermelon in South Korea, 2008-2012. Res. Plant Dis. 2014, 20, 8-14. [CrossRef]

22. Bahar, O.; Kritzman, G.; Burdman, S. Bacterial fruit blotch of melon: screens for disease tolerance and role of seed transmission in pathogenicity. Eur. J. Plant Pathol. 2009, 123, 71-83. [CrossRef]

23. Burdman, S.; Kots, N.; Kritzman, G.; Kopelowitz, J. Molecular, physiological, and host-range characterization of Acidovorax avenae subsp. citrulli isolates from watermelon and melon in Israel. Plant Dis. 2005, 89, 1339-1347. [CrossRef] [PubMed]

24. Tian, Q.; Feng, J.-J.; Hu, J.; Zhao, W.-J. Selective detection of viable seed-borne Acidovorax citrulli by real-time PCR with propidium monoazide. Sci. Rep. 2016, 6, 35457. [CrossRef] [PubMed]

25. Schaad, N.W.; Sechler, A. An improved semiselective agar medium for Acidovorax avenae subsp. citrulli. Phytopathology 1999, 89 (Suppl. 6), 68-69.

26. Zhao, T.; Feng, J.; Sechler, A.; Randhawa, P.; Li, J.; Schaad, N.W. An improved assay for detection of Acidovorax citrulli in watermelon and melon seed. Seed Sci. Technol. 2009, 37, 337-349. [CrossRef]

27. Venette, J.; Lamppa, R.; Albaugh, D.; Nayes, J. Presumptive procedure (dome test) for detection of seedborne bacterial pathogens in dry beans. Plant Dis. 1987, 71, 984-990. [CrossRef]

28. Feng, J.; Xu, Y.; Li, J.; Schaad, N. Comparison of immunostrip and real-time fluorescent PCR (TaqMan) for detection of Acidovorax avenae subsp. citrulli, the causal agent of bacterial fruit blotch of watermelon. Acta Phytopathol. Sin. 2006, 36, 102-108.

29. Himananto, O.; Thummabenjapone, P.; Luxananil, P.; Kumpoosiri, M.; Hongprayoon, R.; Kositratana, W.; Gajanandana, O. Novel and Highly Specific Monoclonal Antibody to Acidovorax citrulli and Development of ELISA-Based Detection in Cucurbit Leaves and Seed. Plant Dis. 2011, 95, 1172-1178. [CrossRef]

30. Horuz, S.; Cetinkaya-Yildiz, R.; Mirik, M.; Aysan, Y. Occurrence, isolation, and identification of Acidovorax citrulli from Melon in Turkey. Plant Protect. Sci. 2014, 50, 179-183. [CrossRef]

31. Kuo, S.-Y.; Lin, Y.-C.; Lai, Y.-C.; Liao, J.-T.; Hsu, Y.-H.; Huang, H.-C.; Hu, C.-C. Production of fluorescent antibody-labeling proteins in plants using a viral vector and the application in the detection of Acidovorax citrulli and Bamboo mosaic virus. PLOS ONE 2018, 13, e0192455. [CrossRef]

32. Matsuura, T.; Shirakawa, T.; Sato, M.; Inoue, Y.; Azegami, K. Detection and isolation of Acidovorax avenae subsp. citrulli from watermelon [Citrullus lanatus] seeds using membrane filtration immunostaining. Jpn. J. Phytopathol. (Japan) 2008. [CrossRef]

33. Melo, L.A.; Tebaldi, N.D.; Mehta, A.; Marques, A.S.A. Comparing Acidovorax citrulli strains from melon and watermelon: Phenotypic characteristics, pathogenicity and genetic diversity. Trop. Plant Pathol. 2014, 39, 154-162. [CrossRef]

34. Puttharugsa, C.; Wangkam, T.; Huangkamhang, N.; Gajanandana, O.; Himananto, O.; Sutapun, B.; Amarit, R.; Somboonkaew, A.; Srikhirin, T. Development of surface plasmon resonance imaging for detection of Acidovorax avenae subsp. citrulli (Aac) using specific monoclonal antibody. Biosens. Bioelectron. 2011, 26, 2341-2346. [CrossRef]

35. Walcott, R.; Fessehaie, A.; Castro, A. Differences in pathogenicity between two genetically distinct groups of Acidovorax avenae subsp. citrulli on cucurbit hosts. J. Phytopathol. 2004, 152, 277-285. [CrossRef] 
36. Wang, Y.; Zhou, Q.; Li, B.; Liu, B.; Wu, G.; Ibrahim, M.; Xie, G.; Li, H.; Sun, G. Differentiation in MALDI-TOF MS and FTIR spectra between two closely related species Acidovorax oryzae and Acidovorax citrulli. BMC Microbiol. 2012, 12, 182. [CrossRef]

37. Zeng, H.; Guo, W.; Liang, B.; Li, J.; Zhai, X.; Song, C.; Zhao, W.; Fan, E.; Liu, Q. Self-paired monoclonal antibody lateral flow immunoassay strip for rapid detection of Acidovorax avenae subsp. citrulli. Anal. Bioanal. Chem. 2016, 408, 6071-6078. [CrossRef] [PubMed]

38. Lee, H.; Kim, M.S.; Qin, J.; Park, E.; Song, Y.-R.; Oh, C.-S.; Cho, B.-K. Raman Hyperspectral Imaging for Detection of Watermelon Seeds Infected with Acidovorax citrulli. Sensors (Basel, Switzerland) 2017, 17, 2188. [CrossRef] [PubMed]

39. Zeng, H.; Zhang, D.; Zhai, X.; Wang, S.; Liu, Q. Enhancing the immunofluorescent sensitivity for detection of Acidovorax citrulli using fluorescein isothiocyanate labeled antigen and antibody. Anal. Bioanal. Chem. 2018, 410, 71-77. [CrossRef]

40. Zhang, J.; Tian, Q.; Zhu, S.-F.; Zhao, W.-J.; Liu, F.-Q. Rapid on-site detection of Acidovorax citrulli by cross-priming amplification. Mol. Cell. Probes 2012, 26, 175-176. [CrossRef]

41. Yan, L.; Zhao, Y.; Zhou, J.; Chen, S.; Bai, S.; Tian, Y.; Gong, W.; Hu, B. Rapid and sensitive detection of Acidovorax citrulli in cucurbit seeds by visual loop-mediated isothermal amplification assay. J. Phytopathol. 2019, 167, 10-18. [CrossRef]

42. Giovanardi, D.; Sutton, S.A.; Stefani, E.; Walcott, R.R. Factors influencing the detection of Acidovorax citrulli in naturally contaminated cucurbitaceous seeds by PCR-based assays. Seed Sci. Technol. 2018, 46, 93-106. [CrossRef]

43. Feng, J.-J.; Kim, J.-Y.; Liu, X.-L.; Schaad, N.W.; Li, J. Differentiation of live and dead cell of bacterial plant pathogen in polymerase chain reaction assays using a DNA binding dye. Chem. J. Chin. U 2008, 29, 944-948.

44. Cho, M.S.; Park, D.H.; Ahn, T.-Y.; Park, D.S. Rapid and specific detection of Acidovorax avenae subsp. citrulli using SYBR green-based real-time PCR amplification of the YD-repeat protein gene. J. Microbiol. Biotechnol. 2015, 25, 1401-1409. [CrossRef]

45. Choi, O.; Cho, S.K.; Kang, B.; Cho, J.; Park, J.; Lee, Y.; Kim, J. Two genetically distinct groups of Acidovorax citrulli are present in watermelon-growing fields in Korea. J. Agric. Life Sci. 2016, 50, 53-59. [CrossRef]

46. Rui, S.; Qing, L.; Yali, L.; Zhaohui, W.; Junping, W.; Liping, Z.; Jianxiong, H.; Zhijie, L. Rapid Immuno-PCR Detection of Acidovorax avenae subsp. citrulli. Plant Quar. 2009, 2.

47. Xu, F.; Wang, X.; Xie, G.; Su, T.; Yu, S. Detection of Acidovorax avenae subsp. citrulli from seeds of watermelon by immuno-capture PCR. J. Fruit Sci. 2008, 2.

48. Walcott, R.; Gitaitis, R. Detection of Acidovorax avenae subsp. citrulli in watermelon seed using immunomagnetic separation and the polymerase chain reaction. Plant Dis. 2000, 84, 470-474. [CrossRef]

49. Amagliani, G.; Omiccioli, E.; Campo, A.; Bruce, I.J.; Brandi, G.; Magnani, M. Development of a magnetic capture hybridization-PCR assay for Listeria monocytogenes direct detection in milk samples. J. Appl. Microbiol. 2006, 100, 375-383. [CrossRef]

50. Eckshtain-Levi, N.; Shkedy, D.; Gershovits, M.; Da Silva, G.M.; Tamir-Ariel, D.; Walcott, R.; Pupko, T.; Burdman, S. Insights from the genome sequence of Acidovorax citrulli M6, a group I strain of the causal agent of bacterial fruit blotch of cucurbits. Front. Microbiol. 2016, 7, 430. [CrossRef] [PubMed]

51. Slovareva, O.Y.; Kornev, K.P.; Matyashova, G.N.; Stakheev, A.A.; Prikhodko, S.I. Recommended Procedure for Detection and Identification Acidovorax citrulli in Seeds; AIP Publishing: Melville, NY, USA, 2019; Volume 2063, p. 030020.

52. Song, J.Y.; Oo, M.M.; Park, S.Y.; Seo, M.W.; Lee, S.-C.; Jeon, N.B.; Nam, M.H.; Lee, Y.S.; Kim, H.G.; Oh, S.-K. Analysis of intraspecific genetic diversity in Acidovorax citrulli causing bacterial fruit blotch on cucurbits in Korea. Korean J. Agric. Sci. 2018, 45, 575-582.

53. Wang, T.; Sun, B.; Yang, Y.; Zhao, T. Genome sequence of Acidovorax citrulli group 1 strain pslb65 causing bacterial fruit blotch of melons. Genome Announc. 2015, 3, e00315-e00327. [CrossRef] [PubMed]

54. Copeland, A.; Lucas, S.; Lapidus, A.; Barry, K.; Detter, J.; Glavina del Rio, T.; Dalin, E.; Tice, H.; Pitluck, S.; Kiss, H. Complete Sequence of Acidovorax avenae subsp. citrulli AAC00-1; US DOE Joint Genome Institute: Walnut Creek, CA, USA, 2006.

55. Park, H.-J.; Seong, H.J.; Sul, W.J.; Oh, C.-S.; Han, S.-W. Complete genome sequence of Acidovorax citrulli strain KACC17005, a causal agent for bacterial fruit blotch on watermelon. J. Microbiol. 2017, 53, 340-341. 
56. Wang, T.; Yang, Y.; Zhao, T. Genome sequence of a copper-resistant strain of Acidovorax citrulli causing bacterial fruit blotch of melons. Genome Announc. 2015, 3, e00310-e00315. [CrossRef] [PubMed]

57. Feng, J.J.; Li, J.Q.; Walcott, R.R.; Zhang, G.M.; Luo, L.X.; Kang, L.; Zheng, Y.; Schaad, N.W. Advances in detection of Acidovorax citrulli, the causal agent of bacterial fruit blotch of cucurbits. Seed Sci. Technol. 2013, 41, 1-15. [CrossRef]

58. Ha, Y.; Fessehaie, A.; Ling, K.; Wechter, W.; Keinath, A.; Walcott, R. Simultaneous detection of Acidovorax avenae subsp. citrulli and Didymella bryoniae in cucurbit seedlots using magnetic capture hybridization and real-time polymerase chain reaction. Phytopathology 2009, 99, 666-678. [CrossRef] [PubMed]

59. Kajiwara, H.; Sato, M.; Suzuki, A. Detection of Acidovorax avenae subsp. citrulli using PCR and MALDI-TOF MS. J. Electrophor. 2012, 56, 13-17. [CrossRef]

60. Song, W.Y.; Kim, H.M.; Hwang, C.Y.; Schaad, N.W. Detection of Acidovorax avenae ssp. avenae in Rice Seeds Using BIO-PCR. J. Phytopathol. 2004, 152, 667-676. [CrossRef]

61. Zivanovic, M.; Walcott, R. Further characterization of genetically distinct groups of Acidovorax citrulli strains. Phytopathology 2016, 107, 29-35. [CrossRef]

62. Wang, T.; Yang, Y.; Zhao, T. Genome Sequence of a Copper-Resistant Strain of span class "named-content genus-species" "named-content-1" Acidovorax citrulli span Causing Bacterial Fruit Blotch of Melons. Genome Announc. 2015, 3, e00310-e00315. [CrossRef]

63. Varghese, N.A.S. Acidovorax citrulli Strain DSM 17060, Whole Genome Shotgun Sequencing Project. Available online: https://www.ncbi.nlm.nih.gov/nuccore/FNEY00000000 (accessed on 15 February 2019).

64. Yan, S.; Yang, Y.; Wang, T.; Zhao, T.; Schaad, N.W. Genetic diversity analysis of Acidovorax citrulli in China. Eur. J. Plant Pathol. 2013, 136, 171-181. [CrossRef]

65. Adhikari, M.; Yadav, D.R.; Kim, S.W.; Um, Y.H.; Kim, H.S.; Lee, S.C.; Song, J.Y.; Kim, H.G.; Lee, Y.S. Biological control of bacterial fruit blotch of watermelon pathogen (Acidovorax citrulli) with rhizosphere associated bacteria. Plant Pathol. J. 2017, 33, 170. [CrossRef] [PubMed]

66. Rahimi-Midani, A.; Lee, Y.S.; Kang, S.-W.; Kim, M.-K.; Choi, T.-J. First Isolation and Molecular Characterization of Bacteriophages Infecting Acidovorax citrulli, the Causal Agent of Bacterial Fruit Blotch. Plant Pathol. J. 2018, 34, 59. [PubMed]

67. Bahar, O.; Efrat, M.; Hadar, E.; Dutta, B.; Walcott, R.; Burdman, S. New subspecies-specific polymerase chain reaction-based assay for the detection of Acidovorax avenae subsp. citrulli. Plant Pathol. 2008, 57, 754-763. [CrossRef]

68. Zhong, J.; Lin, Z.-Y.; Ma, Y.-M.; Gao, B.-D.; Liu, H.-Q.; Zhao, T.-C.; Schaad, N.W. Rapid Discrimination between Groups I and II of Acidovorax citrulli Using a Primer Pair Specific to a pil L Gene. J. Phytopathol. 2016, 164, 558-562. [CrossRef]

69. Song, J.Y.; Park, S.Y.; Seo, M.W.; Nam, M.H.; Lim, H.S.; Lee, S.-C.; Lee, Y.S.; Kim, H.G. Genetic characteristics of Acidovorax citrulli population causing bacterial fruit blotch against cucurbits in Korea. Res. Plant Dis. 2015, 21, 82-88. [CrossRef]

70. Walcott, R.R.; Gitaitis, R.D.; Castro, A.C. Role of Blossoms in Watermelon Seed Infestation by Acidovorax avenae subsp. citrulli. Phytopathology 2003, 93, 528-534. [CrossRef]

71. Oya, H.; Nakagawa, H.; Saito, N.; Uematsu, H.; Ohara, T. Detection of Acidovorax avenae subsp. citrulli from seed using LAMP method. Jpn. J. Phytopathol. (Japan) 2008. [CrossRef]

72. Tian, Y.; Xu, J.; Zhao, Y.; Li, X.; Hu, B.; Liu, F. Specific detection of Acidovorax avenae subsp. citrulli by PCR. Jiangsu J. Agric. Sci. 2010, 26, 512-516.

73. Rubel, M.H.; Robin, A.H.K.; Natarajan, S.; Vicente, J.G.; Kim, H.-T.; Park, J.-I.; Nou, I.-S. Whole-Genome re-alignment facilitates development of specific molecular markers for races 1 and 4 of Xanthomonas campestris pv. campestris, the cause of black rot disease in Brassica oleracea. Int. J. Mol. Sci. 2017, 18, 2523. [CrossRef]

74. Rubel, M.H.; Hossain, M.R.; Nath, U.K.; Natarajan, S.; Lee, J.-H.; Jung, H.-J.; Kim, H.-T.; Park, J.-I.; Nou, I.-S. Development of a PCR test for detection of Xanthomonas campestris pv. raphani. Australas. Plant Pathol. 2019, 48, 179-182. [CrossRef]

75. Rubel, M.H.; Natarajan, S.; Hossain, M.R.; Nath, U.K.; Afrin, K.S.; Lee, J.-H.; Jung, H.-J.; Kim, H.-T.; Park, J.-I.; Nou, I.-S. Pathovar specific molecular detection of Xanthomonas campestris pv. campestris, the causal agent of black rot disease in cabbage. Can. J. Plant Pathol. 2019. [CrossRef] 
76. Larrea-Sarmiento, A.; Dhakal, U.; Boluk, G.; Fatdal, L.; Alvarez, A.; Strayer-Scherer, A.; Paret, M.; Jones, J.; Jenkins, D.; Arif, M. Development of a genome-informed loop-mediated isothermal amplification assay for rapid and specific detection of Xanthomonas euvesicatoria. Sci. Rep. 2018, 8, 14298. [CrossRef] [PubMed]

77. Zhang, Y.; Zhang, S.; Zhang, G.; Liu, X.; Wang, C.; Xu, J. Comparison of mitochondrial genomes provides insights into intron dynamics and evolution in the caterpillar fungus Cordyceps militaris. Fungal Genet. Biol. 2015, 77, 95-107. [CrossRef] [PubMed]

78. Jeong, J.-Y.; Robin, A.H.K.; Natarajan, S.; Laila, R.; Kim, H.-T.; Park, J.-I.; Nou, I.-S. Race- and Isolate-specific Molecular Marker Development through Genome-Realignment Enables Detection of Korean Plasmodiophora brassicae Isolates, Causal agents of Clubroot Disease. Plant Pathol. J. 2018, 34, 506-513. [CrossRef] [PubMed]

79. Davidson, A.L.; Dassa, E.; Orelle, C.; Chen, J. Structure, function, and evolution of bacterial ATP-binding cassette systems. Microbiol. Mol. Biol. Rev. MMBR 2008, 72, 317-364. [CrossRef] [PubMed]

80. Tanaka, K.J.; Song, S.; Mason, K.; Pinkett, H.W. Selective substrate uptake: The role of ATP-binding cassette (ABC) importers in pathogenesis. Biochim. Biophys. Acta (BBA) Biomembr. 2018, 1860, 868-877. [CrossRef] [PubMed]

81. De Buck, E.; Lammertyn, E.; Anné, J. The importance of the twin-arginine translocation pathway for bacterial virulence. Trends Microbiol. 2008, 16, 442-453. [CrossRef] [PubMed]

82. Lavander, M.; Ericsson, S.K.; Bröms, J.E.; Forsberg, A. The twin arginine translocation system is essential for virulence of Yersinia pseudotuberculosis. Infect. Immun. 2006, 74, 1768-1776. [CrossRef] [PubMed]

83. Lee, P.A.; Tullman-Ercek, D.; Georgiou, G. The Bacterial Twin-Arginine Translocation Pathway. Annu. Rev. Microbiol. 2006, 60, 373-395. [CrossRef] [PubMed]

84. Hashimoto, W.; Itoh, T.; Maruyama, Y.; Mikami, B.; Murata, K. Hydration of vinyl ether groups by unsaturated glycoside hydrolases and their role in bacterial pathogenesis. Int. Microbiol. 2007, 10, 233-243. [PubMed]

85. Olivera, I.E.; Fins, K.C.; Rodriguez, S.A.; Abiff, S.K.; Tartar, J.L.; Tartar, A. Glycoside hydrolases family 20 (GH20) represent putative virulence factors that are shared by animal pathogenic oomycetes, but are absent in phytopathogens. BMC Microbiol. 2016, 16, 232. [CrossRef] [PubMed]

86. Sjögren, J.; Collin, M. Bacterial glycosidases in pathogenesis and glycoengineering. Future Microbiol. 2014, 9 , 1039-1051. [CrossRef]

87. Wechter, W.P.; Levi, A.; Ling, K.-S.; Kousik, C.; Block, C.C. Identification of resistance to Acidovorax avenae subsp. citrulli among melon (Cucumis spp.) plant introductions. HortScience 2011, 46, 207-212. [CrossRef]

88. Carvalho, F.C.; Santos, L.A.; Dias, R.C.; Mariano, R.L.; Souza, E.B. Selection of watermelon genotypes for resistance to bacterial fruit blotch. Euphytica 2013, 190, 169-180. [CrossRef] 